\title{
PENGGUNAAN METODE PEMBELAJARAN THINK PAIR AND SHARE DALAM MENINGKATKAN HASIL BELAJAR MATA PELAJARAN IPS KELAS VI SEKOLAH DASAR NEGERI SAWAH 2 CIPUTAT
}

\author{
Mirna Herawati \\ Dosen Program Studi Pendidikan Ekonomi Universitas Indraprasta PGRI \\ e-mail : mirnathar19@gmail.com
}

\begin{abstract}
Abstrak
Penelitian ini bertujuan untuk mengetahui : adanya pengaruh yang signifikan penggunaan metode pembelajaran think pair and share terhadap hasil belajar mata pelajaran IPS kelas VI SD Negeri Sawah 2 Ciputat. Metode yang digunakan dalam penelitian ini adalah metode eksperimen, yaitu dengan memberikan metode pengajaran yang berbeda pada dua kelompok, yaitu kelompok satu dengan model pembelajaran Think pair and share dan kelompok dua dengan metode pembelajaran ceramah. Adapun simpulan penelitian menunjukkan bahwa terdapat rata-rata hasil belajar mata pelajaran IPS kelompok siswa yang diberi metode pembelajaran menggunakan model pembelajaran think pair and share lebih tinggi dari pada rata-rata hasil belajar kelompok siswa yang diberi metode pembelajaran konvensional atau dengan kata lain pemberian metode pembelajaran menggunakan model pembelajaran think pair and share mempunyai pengaruh dalam meningkatkan hasil belajar mata pelajaran IPS siswa Sekolah Dasar Negeri Sawah 2 Ciputat. Dari hasil pengujian hipotesis statistik diperoleh statistik data nilai $t_{\text {hitung }}=4,26$ dan $\mathrm{t}_{\text {tabel }}=1,68$ pada taraf $5 \%$ yang berarti nilai $\mathrm{t}_{\text {hitung }}>\mathrm{t}_{\text {tabel. }}$. Hasil tersebut menunjukkan bahwa $\mathrm{H}_{0}$ ditolak dan $\mathrm{H}_{1}$ diterima. Dengan diterimanya $\mathrm{H}_{1}$, hal ini berarti telah membuktikan kebenaran dari hipotesis dengan demikian penggunaan metode pembelajaran think pair and share berpengaruh terhadap hasil belajar mata pelajaran IPS siswa.
\end{abstract}

Kata kunci : metode pembelajaran think pair and share, ceramah, hasil belajar

\section{PENDAHULUAN}

Pendidikan tidak terlepas dari dunia sekolah, yang mana sekolah merupakan lembaga pendidikan formal dan sekolah menghendaki peserta didiknya mempunyai prestasi belajar yang baik. Pendidikan dapat terlaksana melalui proses belajar mengajar, dimana guru merupakan salah satu faktor penentu keberhasilan setiap upaya pendidikan, itulah sebabnya setiap adanya inovasi pendidikan khususnya dalam hal pembelajaran selalu bermuara pada faktor guru. Hal ini menunjukan betapa pentingnya peran guru terhadap dunia pendidikan.

Dalam proses belajar mengajar guru harus menguasai materi pembelajaran yang diajarkan dengan baik, menentukan tujuan pembelajaran yang ingin dicapai. memilih metode yang tepat dan menggunakan strategi yang dapat mengaktifkan siswa dalam belajar.

Menurut James dalam Sanjaya (2009:14) mengemukan bahwa:

“seorang guru perlu memilki kemampuan merancang dan mengimplementasikan berbagai strategi pembelajaran yang dianggap cocok dengan minat dan bakat serta sesuai dengan taraf perkembangan siswa termasuk didalamnya 
memanfaatkan berbagai sumber dan media pembelajaran untuk menjamin efektivitas pembelajaran”.

Tanpa adanya hal diatas guru tidak dapat mengajar dengan baik dan proses belajar mengajar tidak berjalan seperti yang diharapkan sehingga tujuan yang diinginkan tidak tercapai.

Hasil belajar mempunyai peranan penting dalam proses pembelajaran. Proses penilaian terhadap hasil belajar dapat memberikan informasi terhadap guru tentang kemajuan siswa dalam menguasai dan menyerap materi pelajaran. Maka proses penilaian hasil belajar sangat diperlukan dalam upaya mencapai tujuan-tujuan pembelajaran melalui kegiatan belajar.

Menurut Slameto (2003:54) menyatakan bahwa:

"untuk memperoleh hasil belajar yang baik, banyak faktor yang perlu di perhatikan. Secara garis besar faktor-faktor yang mempengaruhi hasil belajar dapat dibedakan menjadi dua bagian yaitu faktor yang berasal dari diri siswa (intern) yang terdiri dari faktor jasmaniah (kesehatan dan cacat tubuh) dan faktor psikologis (kecerdasan, konsentrasi, motivasi dan bakat). Sedangkan faktor yang bersal dari luar siswa (ekstern) terdiri dari faktor lingkungan keluarga, lingkungan sekolah, dan lingkungan masyarakat”.

Untuk memperoleh hasil yang baik, bukanlah hasil yang mudah bagi setiap siswa, karena didalam dunia pendidikan tidak sedikit yang mengalami kegagalan. Kadang kala ada siswa yang memiliki dorongan yang kuat untuk mendapatkan prestasi dan kesempatan untuk meningkatkan hasil belajar. Tetapi dalam kenyataannya tidak sesuai dengan yang diharapkan.

Untuk itu guru sebagai fasilitator dan motivator dalam mengoptimalkan belajar siswa sebaiknya memilih strategi yang dapat mengaktifkan siswa dalam belajar sehingga dapat mengaktifkan siswa. Sedangkan menurut Slavin (2009:8): "model pembelajaran kooperatif diartikan sebagai lingkungan belajar dimana siswa belajar bersama dalam kelompok kecil yang mempunyai akademik berbeda, didalam kooperatif siswa dibagi 4-6 orang siswa, yang dibagi secara heterogen dalam hal akademik, jenis kelamin dan kebudayaan”.

Banyak metode yang diterapkan guru dalam mengajar diantaranya metode pembelajaran kooperatif Think Pair and Share (TPS). 
Menurut Lie (2007:57) menyatakan bahwa :

“TPS adalah teknik belajar mengajar, berpikir, berpasangan dan berbagi. pendekatan ini dirancang untuk mempengaruhi pola interaksi siswa. Keunggulan dari pembelajaran TPS adalah meningkatkan partisipasi siswa, dimana menghendaki siswa lebih banyak berfikir, menjawab dan saling membantu satu sama lain dalam kelompok kecil yang heterogen. Sehingga siswa merasa lebih terlibat dalam proses pembelajaran”.

Berdasarkan hal-hal tersebut, maka dalam penelitian ini akan mengkaji tentang tentang "Penggunaan Metode Pembelajaran Think Pair and Share dapat Mempengaruhi Hasil Belajar Mata Pelajaran IPS Kelas VI Sekolah Dasar Negeri Sawah 2 Ciputat”.

Adapun dari tujuan penelitian ini adalah untuk mengetahui pengaruh model pembelajaran Think Pair and Share terhadap hasil belajar mata pelajaran IPS Kelas VI Sekolah Dasar Negeri Sawah 2 Ciputat.

\section{TINJAUAN PUSTAKA}

\section{Pengertian hasil belajar}

Menurut slameto (2003:2) belajar adalah "suatu proses usaha yang dilakukan seseorang untuk memperoleh suatu perubahan tingkah laku yang baru secara keseluruhan, proses belajar mengajar berlangsung dalam suatu kondisi yang dinamakan interaksi edukatif, akhir dari interaksi akan didapat hasil belajar”. Hasil belajar mempunyai peranan penting dalam proses pembelajaran. Proses penilaian terhadap hasil belajar dapat memberikan informasi kepada guru terhadap kemajuan siswa dalam upaya mencapai tujuan-tujuan pembelajaran.

Sudjana (2009:7) berpendapat bahwa hasil belajar adalah "kemampuankemampuan yang dimiliki siswa setelah menerima pengalaman belajarnya yang meliputi kemampuan kognitif, afektif, dan psikomotor (Bloom)”. Hasil belajar merupakan milik siswa yang yang diperoleh setelah mengikuti proses belajar mengajar, baik itu merupakan kemampuan siswa menguasai materi yang telah dilakukanmaupun berupa sikap atau keterampilan yang dimiliki siswa.

Menurut Mudjiono (2006:4) hasil belajar adalah "hasil dari suatu interaksi tindak belajar dan tindak mengajar”. Sedangkan menurut Ishaq (2007:6) hasil belajar merupakan "penguasaan, pemahaman, kemampuan siswa dalam menyerap bahan 
pengajaran dalam proses interaksi edukatif”. Dari pengertian-pengertian tersebut dapat disimpulkan bahwa hasil belajar merupakan kemampuan-kemampuan yang dimiliki siswa dalam menyerap materi pelajaran dari interaksi tindak belajar dan tindak mengajar.

\section{Faktor-Faktor yang Mempengaruhi Hasil Belajar}

Menurut Slameto (2003:54) "faktor-faktor yang mempengaruhi hasil belajar dapat digolongkan menjadi 2 bagian yaitu faktor intern dan faktor ekstern”.

1. Faktor intern

Adalah faktor yang berasal dari dalam diri siswa yang terdiri dari:

a. Faktor jasmani yang meliputi faktor kesehatan dan cacat tubuh.

b. Faktor psikologis yang meliputi minat dan konsentrasi, kecerdasan (kemampuan), bakat, motivasi, sikap.

2. Faktor ekstern

Adalah faktor yang berasal dari luar siswa yang terdiri dari:

a. Lingkungan keluarga, terdiri cara orang tua mendidik anak, relasi antar anggota keluarga,suasana rumah, keadaan ekonomi keluarga, pengerian orang tua, latar belakang kebudayaan. Hal tersebut selalu berpengaruh terhadap hasil belajar siswa disekolah.

b. Lingkungan sekolah, hal yang mempengaruhi hasil belajar disekolah antara lain: metode mengajar, kurikulum, hubungan guru dengan siswa, siswa dengan siswa, disiplin sekolah, alat pelajaran, waktu sekolah,keadaan gedung, metode mengajar dan tugas rumah.

c. Lingkungan masyarakat, berbagai hal yang dapat mempengaruhi hasil belajar siswa yang bersumber dari masyarakat terdiri dari : kegiatan siswa dalam masyarakat, media masa (elektronik dan cetak), teman bermain, kegiatan luar sekolah, serta suasana lingkungan tempat tinggal yang berbeda antara satu dengan yang lainnya.

Dari pendapat diatas dapat diketahui bahwa faktor yang mempengaruhi hasil belajar siswa dapat dipengaruhi oleh 2 faktor. Faktor-faktor tersebut berasal dari dalam diri siswa sendiri dan ada juga yang berasal dari luar siswa seperti faktor lingkungan yang meliputi lingkungan keluarga, sekolah, dan masyarakat di lingkungan siswa. 


\section{Hakikat Pembelajaran IPS}

Menurut Ahmad Susanto (2013:137) menyatakan bahwa:

"Ilmu pengetahuan sosial, yang sering disingkat dengan IPS adalah ilmu pengetahuan yang mengkaji berbagai disiplin ilmu sosial dan humaniora serta kegiatan dasar manusia yang dikemas secara ilmiah dalam rangka memberi wawasan dan pemahaman yang mendalam kepada peserta didik, khususnya di tingkat dasar dan menengah. Luasnya kajian IPS ini mencakup berbagai kehidupan sosial, ekonomi, psikologi, budaya, sejarah maupun politik, semuanya dipelajari dalam ilmu sosial ini”.

Dalam Kurikulum Pendidikan Dasar Tahun 1993, disebutkan bahwa IPS adalah mata pelajaran yang mempelajari kehidupan sosial yang didasarkan pada bahan kajian geografi, ekonomi, sejarah, antropologi, sosiologi, dan tata Negara. Khusus di sekolah lanjutan tingkat pertama program IPS hanya mencakup bahan kajian geografi, ekonomi, dan sejarah. Sedangkan pendidikan IPS di sekolah dasar merupakan bidang studi yang mempelajari manusia dalam semua aspek kehidupan dan interaksinya dalam masyarakat (Ahmad Susanto, 2013:143).

Ruang lingkup pebgajaran IPS pada jenjang pendidikan dasar dibatasi sampai gejala dan masalah sosial yang dapat dijangkau pada geografi dan sejarah. Terutama gejala dan masalah sosial kehidupan sehari-hari yang ada di lingkungan sekitar peserta didik di MI/SD (Irfan, 2009:111).

Adapun tujuan pembelajaran IPS MI adalah untuk mendidik dan memberi bekal kemampuan dasar kepada siswa-siswi untuk mengembangkan diri sesuai bakat, minat dan kemampuan dan lingkungannya dalam bidang pembelajaran IPS SD (Agung Eko, 2009:111). Selain tujuan di atas secara umum tujuan pembelajaran IPS atau tujuan instruksional IPS yang dilaksanakan selama ini sekurang-kurangnya sebagai berikut:

1. Membekali peserta didik dengan pengetahuan sosial yang berguna dalam kehidupan masyarakat.

2. Membekali peserta didik dengan kemampuan mengidentifikasi, menganalisa, dan menyusun alternatif pemecahan masalah sosial yang terjadi dalam kehidupan masyarakat.

3. Membekali peserta didik dengan kemampuan berkomunikasi dengan sesama warga masyarakat dan dengan berbagai bidang keilmuan serta berbagai keahlian. 
4. Membekali peserta didik dengan kesadaran, sikap mental yang positif, dan keterampilan terhadap lingkungan hidup yang menjadi bagian dari kehidupannya yang tidak terpisahkan.

5. Membekali peserta didik dengan kemampuan mengembangkan pengetahuan dan keilmuan IPS sesuai dengan perkembangan kehidupan, perkembangan masyarakat, perkembangan ilmu, dan teknologi. (Agung Eko, 2009:139).

Dari pengertian diatas, menunjukkan bahwa IPS merupakan perpaduan antara ilmu sosial dan kehidupan manusia yang didalamnya mencakup antropologi, ekonomi, geografi, sejarah, hukum, filsafat, ilmu politik, sosiologi, agama, dan psikologi. Dimana tujuan utamanya adalah membantu mengembangkan kemampuan dan wawasan siswa yang menyeluruh tentang berbagai aspek ilmu-ilmu sosial dan kemanusiaan (humaniora).

Namun sesuai dengan tingkat perkembangannya, siswa SD belum mampu memahami dan memecahkan masalah sosial secara mendalam dan utuh dalam kehidupan sosial masyarakat. Untuk itu pembelajaran IPS di sekolah dasar dimaksudkan agar siswa dapat memperoleh pengetahuan, keterampilan, dan contoh sikap sebagai bekal untuk menghadapi hidup dengan segala tantangannya. Selain itu, diharapkan melalui pembelajaran IPS kelak siswa mampu mengembangkan kemampuan berpikir logis dan kritis dalam memecahkan masalah-masalah yang terjadi di masayarakat. Dengan demikian, sehubungan dengan pengertian hasil belajar dan pembelajaran IPS yang telah dijabarkan di atas dapat disimpulkan bahwa hasil belajar IPS merupakan hasil optimal siswa baik dalam aspek kognitif, afektif, ataupun psikomotorik yang diperoleh siswa setelah memperlajari IPS dengan jalan mencari berbagai informasi yang dibutuhkan baik berupa perubahan tingkah laku, pengetahuan, maupun keterampilan sehingga siswa tersebut mampu mencapai hasil maksimal belajarnya sekaligus memecahkan masalah yang berkaitan dengan masalah sosial dan menerapkannya dalam kehidupan masyarakat.

\section{Model Pembelajaran Kooperatif tipe Think Pair and Share (TPS)}

Berikut merupakan penjelasan mengenai model pembelajaran kooperatif tipe TPS.

TPS sebagai struktur kegiatan pembelajaran kelompok TPS tumbuh dari pembelajaran kooperatif yang memberi siswa kesempatan bekerja sendiri serta 
bekerjasama dengan orang lain (Lie, 2007:57). pembelajaran kooperatif tipe TPS atau berfikir-berpasangan-berbagi dikembangkan oleh Franklyman dalam Arends (2008:15). Pendekatan ini menekankan penggunaan struktur tertentu yang dirancang untuk mempengaruhi pola interksi siswa, juga dikembangkan untuk meningkatkan perolehan isi akademik penerapan model pambelajaran kooperatif tipe TPS ini memiliki prosedur yang eksplisit untuk memberikan siswa waktu yang lebih banyak untuk berfikir, menjawab dan saling membantu satu sama lain.

Dalam model pembelajaran kooperatif tipe TPS siswa dibagi dalam kelompok kecil yang memiliki kemampuan yang berbeda-beda. Baik secara akademis maupun jenis kelamin untuk menyelesaikan tugas akademik. Siswa belajar bersama dalam kelompok kecil yang heterogen. TPS ditandai dengan adanya struktur tugas, struktur tujuan dan struktur penghargaan, dimana siswa dituntut bekerjasama dan saling ketergantungan. Dalam penelitian ini peneliti membagi kelompok beranggotakan dua orang atau sepasang yang dipilih berdasarkan nilai hasil belajar siswa pada materi pokok sebelumnya.

\section{Langkah-Langkah Model Pembelajaran Kooperatif tipe TPS}

Penerapan pembelajaran TPS dalam pelajaran dilaksanakan melalui tahap persiapan, penyajian kelas, kegiatan kelompok dan menghitung ulang skor dasar setiap kelompok.

1. Persiapan

Pada tahap ini disiapakan materi yang akan disajikan dalam pembelajaran, membagi siswa dalam kelompok kooperatif. Jumlah angggota tiap kelompok adalah 2 orang. Kelompok yang dibentuk ini bersifat heterogen secara akademik terdiri dari siswa pandai, sedang dan kurang. Selain itu juga mempertimbangkan kriteria heterogen lain, misalnya jenis kelamin dan latar belakang sosial. Kelompok kooperatif dibentuk berdasarkan pada skor dasar yang diambil dari skor hasil belajar siswa pada materi pokok sebelumnya. Sebelum menyajikan materi pembelajaran, terlebih dahulu dibuat Silabus, Rencana Pelaksanaan Pembelajaran (RPP) dan Lembaran Kerja Siswa (LKS) yang akan dipelajari dan dikerjakan oleh siswa di dalam kelompok. 


\section{Pelaksanaan}

a. Pendahuluan.

Pada pendahuluan ini guru menekankan apa yang akan dipelajari siswa dalam kegiatan kelompok pada model pembelajaran kooperatif tipe TPS dan menginformasikan mengapa hal ini penting dipelajari.Dengan tujuan ingin memotivasi rasa ingin tahu tentang konsep-konsep yang akan mereka pelajari. Jadi intinya disini guru memotivasi siswa dan mengkaitkan materi sekarang dengan materi terdahulu.

b. Kegiatan inti.

Pada kegiatan ini guru menyampaikan materi pelajaran yang sesuai dengan apa yang akan dipelajari siswa. Kemudian dilanjutkan dengan kegiatan TPS yang merupakan kegiatan yang dilakukan oleh siswa yaitu belajar dalam kelompok. Tahap-tahap dalam TPS sebagai berikut:

a. Thinking (berfikir)

Guru mengajukan pertanyaan atau isu yang berhubungan dengan pelajaran atau setelah guru membagikan LKS, kemudian siswa diminta untuk memikirkan pertanyaan atau isu tersebut secara mandiri untuk beberapa saat. Siswa perlu diajari bahwa berbicara tidak menjadi bagian dari waktu berpikir.

b. Pairing (berpasangan)

Guru meminta siswa berpasangan dengan siswa yang lain untuk mendiskusi apa yang telah dipikirkannya pada saat Thinking. Interaksi pada tahap ini diharapkan dapat berbagai jawaban atau ide jika suatu persoalan khusus telah diidentifikasi. Biasanya guru memberi waktu 4-5 menit untuk berpasangan.

c. Share (berbagi)

Pada tahap akhir, guru meminta pada pasangan untuk berbagi dengan seluruh kelas tentang apa yang telah mereka bicarakan. Ini efektif dilakukan dengan cara bergiliran pasangan demi pasangan dan dilanjutkan sampai sekitar seperempat pasangan telah mendapatkan kesempatan untuk melaporkan. Kemudian guru memberikan kesempatan kepada siswa untuk bertanya. 
c. Penutup.

Merupakan kegiatan akhir dari kegiatan pembelajaran, disini guru melakukan evaluasi lebih kurang 15 menit dan menentukan nilai terhadap penghargaan kelompok dan individual.

\section{Keunggulan Model Pembelajaran Kooperatif tipe TPS}

Menurut Lie (2007:57) menyatakan bahwa: "keunggulan dari pembelajaran kooperatif tipe ini adalah dapat meningkatkan partisipasi siswa”. Selain itu menghendaki siswa untuk lebih banyak berpikir, menjawab dan saling membantu satu sama lain dalam kelompok kecil yang heterogen baik secara akademik maupun jenis kelamin. Dengan demikian, diharapkan siswa lebih aktif belajar untuk menyelesaikan tugas-tugas akademik.

\section{Hubungan Model Pembelajaran Kooperatif tipe TPS dengan hasil belajar}

Model pembelajaran kooperatif tipe TPS merupakan lingkungan belajar dimana siswa bekerja sama saling membantu dalam bentuk kecil dan memberi waktu yang lebih banyak untuk berpikir kepada siswa sehingga siswa lebih aktif dalam belajar. Hubungan model pembelajaran kooperatif tipe TPS dengan hasil belajar dapat ditinjau dari setiap tahap pelaksanaan, pada tahap awal pelaksanaan model pembelajaran kooperatif TPS setiap siswa berpikir sendiri dulu dan dilanjutkan dengan diskusi kelompok untuk mengerjakan soal-soal yang terdapat dalam LKS pada tahap ini peran setiap anggota kelompok sangat diharapkan sehingga semua anggota kelompok akan terlibat aktif hal ini akan memotivasi siswa untuk mempelajari materi.

Pada tahap pelaksanaan model pembelajaran kooperatif tipe TPS setiap siswa terlibat interaksi langsung dimana setelah siswa berpikir sendiri maka dia akan bertukar pikiran dalam kelompoknya, sehingga tugasnya dapat terselesaikan, dan pada akhirnya hasil belajarnya akan semakin meningkat karena setiap siswa aktif. Model pembelajaran kooperatif tipe TPS diharapkan agar dapat meningkatkan pemahaman siswa terhadap konsep-konsep IPS yang akhirnya akan meningkatkan hasil belajar siswa. Dengan adanya kerja sama dan tanggung jawab individu atas ketuntasan materi yang ditugaskan kepadanya, maka setiap anggota kelompok dituntut menguasai materinya, sehingga setiap individu termotivasi untuk belajar lebih baik untuk mendapatkan penghargaan kelompok, dengan demikian siswa akan mendapatkan hasil belajar IPS yang lebih baik. 


\section{METODE}

Menurut Arikunto (2006: 160) “metode penelitian adalah cara yang digunakan oleh peneliti dalam mengumpulkan data penelitiannya”. Metode yang digunakan dalam penelitian ini adalah metode eksperimen, yaitu dengan memberikan metode pengajaran yang berbeda pada dua kelompok, yaitu kelompok satu dengan model pembelajaran Think pair and share dan kelompok dua dengan metode pembelajaran ceramah.

\section{HASIL DAN PEMBAHASAN}

\section{Menentukan Harga thitung}

Untuk menguji hipotesis selisih rata-rata antara kelompok 1 dan kelompok 2 menggunakan rumus:

$\mathrm{t}=\frac{\bar{X}_{1}-\bar{X}_{2}}{S D \sqrt{\frac{1}{n_{1}}+\frac{1}{n_{2}}}}$ dengan $\mathrm{S}^{2}=\frac{\left(n_{1}-1\right) S_{1}{ }^{2}-\left(n_{2}\right) S_{2}{ }^{2}}{n_{1}+n_{2}-2}$

dari analisis data didapat:

$\mathrm{S}_{1}^{2}=75,78$

$\mathrm{S}_{2}{ }^{2}=45,78$

$\bar{X}_{1}=80,5 \quad \bar{X}_{2}=70$

Maka:

$$
\begin{aligned}
S & =\sqrt{\frac{19(75,78)+19(45,78)}{20+20-2}} \\
& =\sqrt{\frac{1439,82+869,82}{38}} \\
& =\sqrt{60,78} \\
& =7,79
\end{aligned}
$$

Sehingga:

$$
\begin{aligned}
t & =\frac{80,5-70}{7,79 \sqrt{\frac{1}{20}+\frac{1}{20}}} \\
& =\frac{10,5}{7,79(0,3162)} \\
& =\frac{10,5}{2,463} \\
& =4,26
\end{aligned}
$$




\section{Menentukan Harga tabel}

Tipe pengujian yang digunakan adalah pengujian satu pihak, dengan $\alpha=0,05$ dan $d k=n_{1}+n_{2}-2$. Jadi $d k=20+20-2$, dari tabel distribusi t didapat harga $t_{0,95}(38)$ $=1,68$

\section{Kriteria Pengujian}

Tolak $\mathrm{H}_{0}$ jika thitung $>\mathrm{t}_{\text {tabel }}$ dan terima untuk kriteria lainnya

\section{Simpulan}

Kriteria $t_{\text {hitung }}>t_{\text {tabel }}(4,26>1,68)$ maka $H_{0}$ ditolak dan $H_{1}$ diterima pada $\alpha=0,05$.

Dengan demikian rata-rata hasil belajar mata pelajaran IPS kelompok siswa yang diberi model pembelajaran think pair and share lebih tinggi secara signifikan dari rata-rata hasil belajar mata pelajaran IPS kelompok siswa yang diberi metode pembelajaran konvensional atau dengan kata lain pemberian metode pembelajaran think pair and share mempunyai pengaruh dalam meningkatkan hasil belajar mata pelajaran IPS siswa kelas VI Sekolah Dasar Negeri Sawah 2 Ciputat. Untuk lebih jelasnya dapat dilihat pada tabel di bawah ini”

Tabel 1

Rekapitulasi Hasil Perhitungan Uji Hipotesis

\begin{tabular}{cccccc}
\hline Kelompok & Sampel & Mean & thitung & $\mathbf{t}_{\text {tabel }}$ & Kesimpulan \\
\hline Eksperimen & 20 & 80,5 & \multirow{2}{*}{4,26} & \multirow{2}{*}{1,68} & \multirow{2}{*}{ Tolak H $\mathrm{H}_{0}$} \\
\hline Kontrol & 20 & 70 & & & \\
\hline
\end{tabular}

Dari tabel 1 terlihat bahwa thitung lebih besar dari tabel $(4,26>1,68)$ maka dapat disimpulkan bahwa $\mathrm{H}_{0}$ ditolak dan $\mathrm{H}_{1}$ diterima dengan taraf signifikansi 5\%.

\section{UCAPAN TERIMAKASIH}

Dengan ini penulis mengucapkan rasa syukur kepada Allah SWT tang telah memberikan rahmat dan hidayah-Nya, serta penulis mengucapkan terimakasih kepada Sekolah Dasar Negeri Sawah 2 Ciputat, serta ucapan teriamaksih kepada semua pihak yang telah membantu.

\section{DAFTAR PUSTAKA}

Agung Eko Purwana. 2009. Pembelajaran IPS MI. Surabaya: Lapis PGMI.

Ahmad Susanto. 2013. Teori Belajar dan Pembelajaran di Sekolah Dasar. Jakarta: Kencana Prenada Media Group. 
Arends, R, I. 2008. Learning To Teach Sixth Edition. American, New york: McGrawHill. Dalam bahasa Indonsia diterbitkan Yogyakarta: Pustaka Pelajar.

Arikunto, S, Suhardjono dan Supardi. 2006. Penelitian Tindakan Kelas..Jakarta: PT. Bumi Aksara.

Irfan Tamwifi,et.al. 2009. Ilmu Pengetahuan Sosial 1. Surabaya: Lapis PGMI.

Ishaq. 2007. Cooperative Learning. Bandung: Alfabeta

Lie, A. 2007. Cooperative Learning, Memperaktikan Cooperative Learning di RuangRuang Kelas. Jakarta: Gramedia Widia Sarana.

Mudjiono, Dimyati. 2006. Belajar dan pembelajaran. Jakarta: PT. Rineke Cipta.

Sanjaya, W. 2009. Strategi pembelajaran berorientasistandar proses pembelajaran. Jakarta: Kencana.

Slameto. 2003. Belajar Dan Faktor-Faktor yang Mempengaruhinya. Jakarta: PT. Rineke Cipta.

Slavin, E Robert. 2009. Cooperative Learning Teori, Riset, dan Praktek. Bandung: Nusa Media.

Sudjana, Nana. 2009. Penilaian Hasil Proses Belajar Mengajar. Bandung: PT. Remaja Rosdakarya. 